\title{
4. When is a journalist not a journalist? Negotiating a new form of advocacy journalism within the environmental movement
}

Commentary: A New Zealand broadcast journalist of 25 years' experience comes under fire from former colleagues after joining the environmental campaigning organisation Greenpeace. The ensuing criticism provides insight into how the mainstream media views itself and how sensitive it might be to any perceived threat to its credibility. It opens up an argument about what constitutes a 'journalist' in a contemporary context. A troubling epoch for journalists facing tight newsroom budgets, news trivialisation, fragmented media spheres and dwindling public confidence in the profession. This commentary examines the argument for new terminology to describe the kind of investigative journalism which might be practised within non-government organisations (NGOs) for a mainly digital audience. It also challenges views on objectivity and bias, positing whether advocacy journalism with strict ethical guidelines produced from within an organisation with a known agenda, may serve the public interest more ably than a fragmented mainstream journalism compromised by less obvious biases.

Keywords: advocacy journalism, bias, credibility, digital media, environmental journalism, ethics, Greenpeace, investigative journalism, newsrooms, New Zealand, NGOs, non-government organisations, objectivity

PHIL VINE

Journalist at Greenpeace NZ, Auckland

- HE OTHER day, as part of my new role, I found myself interviewing a 30-year-old Greenpeace activist. It was a fascinating deposition of quiet radicalisation. She had decided to do something that was, by her own assessment, completely out of character. After a lifetime of obeying the norms of society, this model citizen without a parking ticket to her name, was preparing to get arrested. It was making her feel decidedly uncomfortable.

'I've always been mortified about breaking the rules,' she told me. 'I never 


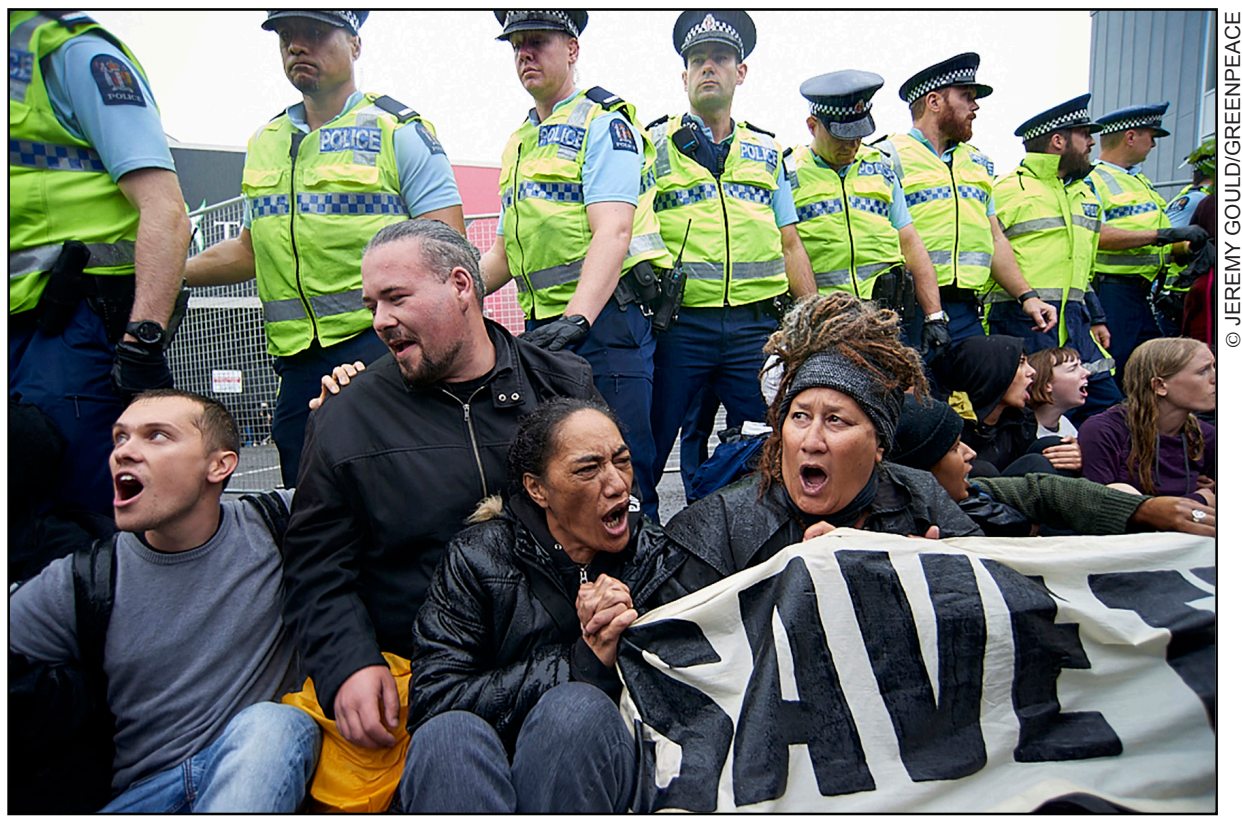

Figure 1: Climate change is a game changer, a disrupter: Protesters blockaded the Petroleum Summit in the New Zealand city of New Plymouth in March 2017 where the government announced a 'block offer' for new gas and oil exploration.

once got a detention at school. Never ever handed an assignment in late. Never got yellow-carded in soccer.'

Her middle school classmates wrote 'Goody Toe Shoes' (sic) under her photo in the yearbook. The reason she gave for abandoning her virtuous track record, for worrying her conservative family and risking a criminal record: Climate change.

'Really?' I wondered. Was she really prepared to be carted off by police because of the concentration of greenhouse gas emissions in the atmosphere?'

'I don't take this decision lightly,' she said. 'Instead I take it out of sheer necessity. Because climate change is threatening our very survival. It affects everyone and everything, and it's about to get a whole lot worse. If we don't act now, we face a truly hellish existence.'

Her positioning is indicative of the fraught landscape we find ourselves in. Climate change is a game changer, a disrupter. It is making radicals of those who would never previously consider putting a foot wrong.

It was climate change too that tipped me out of mainstream journalism into the ranks of Greenpeace. While I feel immediately completely comfortable with the move, my former colleagues, not so much. Like the activist I've just finished talking to, they are experiencing various degrees of discomfort.

On face value, taking the position at Greenpeace wasn't such an unusual move. After all Bob Hunter, probably the most famous co-founder of Greenpeace, 
left journalism to start the organisation (Founders of Greenpeace, 2016). Dozens of journalists have been through these doors over the years. The links between journalism and Greenpeace are many and varied. Why then the indignant outcry from former colleagues?

'Is he kidding himself?' asked Mediawatch on National radio. In essence it wasn't so much 'crossing to the dark side' as Colin Peacock, the interviewer put it (Peacock, 2017) but simply that I had the audacity to keep describing myself as a journalist.

When I took the role at the environmental lobby group there was some discussion over what my exact job title should be. I pushed for 'Journalist at Greenpeace'. More than just a nostalgic yearning or an affectation, I hoped, I wanted it to be a statement of intent. After all Greenpeace had hired me for my investigative journalism skills and that's what I intended to keep on doing.

At Greenpeace UK two years ago, they started up an investigative journalism unit (Jackson, 2015). The organisation took on BBC and New York Times journos working within the organisation to expose environmental wrongdoings.

One of the investigation unit's big stories was to expose a swathe of safety breaches at BP installations around the globe (McClenaghan \& Carter, 2016). A very solid piece of investigative journalism which is what you would expect from reporters of this calibre.

Regardless of what was going on in the UK, New Zealand journalists took umbrage at my job description. Certain of them made it plain that by crossing this perceived rubicon between 'recognised' media and a campaigning organisation 'with an agenda', meant that I would have to leave the tribe, hang up my pork pie hat with the reporter card in it. In footballing terms they seemed to see it as a clear case of divided loyalty. I'd taken on the manager's job at Liverpool while still insisting on wearing an Arsenal scarf at every game.

'Do you have a moral problem with this?' Asked NBR Radio, the broadcasting arm of the country's main business publication National Business Review (Walker, 2017) 'Why should I?' My argument is that the world is rapidly changing and we will have to start to accept that journalism can be practised anywhere and will continue to turn up in different places in this shrinking and fragmenting media sphere. What counts is the standard of the journalism, not the shape of the medium.

One of the interesting lines of attack from mainstream media was that a journalist working within an NGO like Greenpeace could not be trusted. This points to a possible reason for the disgruntlement - fallout from a crisis of credibility facing mainstream media with one symptom being a hypersensitivity to anything which might bring the profession into further disrepute.

I speak as someone who's experienced that drop in confidence and loss of audience. I reported and presented for populist prime time current affairs shows on New 
Zealand television-60 minutes, 20/20, Campbell Live, Fair Go, Sunday, Third Degree, $3 D$ - all of which relied heavily on public confidence for social licence.

As the new millennium progressed we watched viewership fall and our programmes go under. Mimicking the tumbling terrestrial ratings, confidence in the media also tracked steadily downwards. Across the developed world this credibility slippage has gone hand-in-hand with hollowed out newsrooms and shrinking resources.

At the turn of the decade journalism in the US was already experiencing a noticeable fall in trust. A Gallup poll in 2012 found

60 percent of Americans have little or no trust in the mass media to report the news fully, accurately and fairly...

And

... the Pew Centre showed a sharp fall in media credibility with a double digit drop in believability ratings compared to the previous decade. (Reavy, 2013)

A new president who bans established legacy media from White House press briefings and attacks their 'fake news' stories - well that's a fairly good snapshot of the current standing of journalism. This would not be taking place if the credibility of the media had not been so fundamentally compromised. It wouldn't have worked for Richard Nixon. Trust in the US media measured before and after the most recent election saw it drop from 40 to 35 per cent (Edelman, 2017a).

On this side of the Pacific, the latest Acumen Edelman Trust Barometer shows the level of trust for New Zealand media is even lower. It sits at 29 percent. Not only is that nine points down from last year, it's significantly less than the global average over 17 countries, which is 43 percent (Edelman, 2017b); which may help explain some of the local sensitivity around journalistic credibility.

Although I have seen no empirical proof of this, I suspect there will be a linkage between falling credibility and a rapid decline in the amount of investigative journalism, particularly on television. It is certainly an area worthy of inquiry. In 2015, the New Zealand mediascape was shaken by the closure of two influential current affairs programmes, Campbell Live and 3D,(1) by Mediaworks, the private company that owned TV3. The closures were characterised by some left wing commentators as an actual threat to democracy (Bradbury, 2015).

This left one single long format primetime current affairs show, Sunday to serve a population of 4 million.

'You almost don't want to make too much noise about Sunday in case someone in an office somewhere remembers it still exists and realises they've forgotten to cancel it,' said a recent review blog. (Henderson, 2017) 
On the newspaper front, journalistic credibility continues to be undermined by a cut-throat clickbait-driven competition between two dominant digital sites, Stuff and The New Zealand Herald. At the time of going to press they were waiting on a Commerce Commission decision as to whether they could merge. This would inevitably lead to further rationalisation and fewer journalists, with obvious effects on credibility.

The last few years have seen a startling race to the bottom powered by virulent comments sections, celeb gossip and tittle-tattle. Reporting highlights like this classic courtesy of media commentator Russell Brown:

For some time last Wednesday, this was the second-lead story on the award-winning website of The New Zealand Herald: A man went to the supermarket and bought some cheese. It was sliced cheese. After he got home with the sliced cheese, he opened the packet and saw that the cheese had mould on it. The man probably thought about taking the cheese back to the supermarket, but he didn’t. (Brown, 2016)

This is why it's hard to accept lessons in trustworthiness from the mainstream. Little wonder then that audiences are deserting traditional media. Management may blame falling attention levels, social media and smartphones but to my mind the unspoken issue of credibility cannot be left out of the equation. There must also be a certain, as yet unmeasured, chicken-and-egg connection between falling audience numbers and falling standards. Another research topic perhaps.

The fascinating thing about the Acumen Edelman Trust Barometer quoted earlier is that the public trust in Non-Government Organisations (NGOs) such as Greenpeace sits at 51 percent. That's 22 points higher than the trust in Media. So it could be said that my going across to 'the dark side' has substantially lifted my credibility with the public, if not with fellow journalists.

Credibility concerns aside, in deserting mainstream journalism I did experience concerns about audience reach. I wondered whether I might become a lonely voice in the wilderness. Since I started at television in the UK in the nineties, I had always had the luxury of being part of a programme which went out every night or every week and attracted a regular viewership.

As an investigative journalist that meant if I came across some dark and dingy doings which needed a light shone on them, I didn't have a Herculean struggle to get the story out. Sure, I had to pitch it to my executive producer, but if I could convince one gatekeeper, it would run. I was inside the gate. What would happen when I was on the other side? How would I reach an audience?

I had my answer within my first two weeks at Greenpeace. We sent out a helicopter to get the first video of the world's largest oil research vessel, the Amazon Warrior, in New Zealand waters. In the little AV unit at Greenpeace we edited these pictures and added scientific infographics explaining how seismic 
blasting works - sonic explosions set off every 8 seconds to see if the sea floor contained any signs of oil. The effects on whales and dolphins and other animals that rely on sonic communication were self-evident. So too the risks of such marginal deep sea oil extraction at a depth much greater than Shell's Deepwater Horizon Rig which exploded in the Gulf of Mexico.

All of this, at a time when our reliance on fossil fuels is feeding climate change. I wrote a voiceover track the length of a short nightly news story-about 69 seconds long. (By comparison the sort of investigative content we hope to be making soon is more in the realms of 20-30 minutes in length) The minute-long video has now been viewed 1.9 million times. A mass audience way beyond the reach of our 200,000-strong Facebook page.

As a trial run it made me realise that the old model, obtaining such information and sharing it with mainstream media, was not the only pathway to a mass audience. Actually we could self-publish and reach people way beyond our supporters and their friends. It wasn't just preaching to the choir. As people get more and more of their information from the likes of Facebook and other social media this sort of audience will surely grow.

Washington University assistant professor of communication Matthew Powers points out that these sort of changes in news media, advocacy and technology are sparking a growth in what he calls 'NGO journalism' (Powers, 2015).

Greenpeace joins a growing number of nongovernmental organisations (NGOs) trying their hand at journalism. Human Rights Watch now assigns photographers and videographers to produce multimedia packages that accompany research reports. Amnesty International employs 'news writers' charged with making the organisation a compelling online portal for human rights news. And in the midst of humanitarian emergencies, Oxfam sends 'firemen' reporters to gather information and offer analysis."

This new form of journalism must maintain high standards of factual accuracy, fairness and thoroughness, if it is to maintain the public credibility afforded NGOs. There is a concern from the mainstream that 'NGO journalism' will be biased. I agree. In the case of Greenpeace it will be biased towards the environment and away from greed and profiteering. But that bias in favour of the planet is intentional and transparent. I would argue that objectivity is an outdated and unachievable myth. As journalists we all come to stories with inherent biasespersonal, financial or institutional. The manifest biases of the mainstream are far less easy to spot.

On a blogsite called Pundit Radio New Zealand, journalist Tim Watkin takes issue:

We all have views, bad days, blind spots and imperfect knowledge. We make human mistakes and even get things wrong, despite the checking 
and double-checking. So I get all the mainstream media failings and don't pretend any of it's perfect. I get Phil's argument that mainstream journalism comes with bias and all the rest. But for me, that's not the point. Those are all problems from the journey, not from your place of origin. Or your intent. (Watkin, 2017)

Tim Watkin is in the unique and privileged position of being able to throw stones from within his own glasshouse. He enjoys the minority sport of public broadcasting where the taxpayer picks up the bill for everything they do. In the vast majority of other outlets you have an ecosystem completely supported by advertising and corporate sponsorship. Every day commercial decisions, large and small, compromise independence.

An example: There was a time when Tim Watkin and I both worked at TVNZ, at one time regarded as a bastion of public interest. The channel is required by the government to return a profit, it carries advertising, so corporate pressures are real and constant. Not long ago I was working at the consumer watchdog show Fair Go. I was in the process of reporting a story which was highly critical of a key advertiser's product. They were not happy. There was a huge amount of high level interference with the implicit threat of a withdrawal of advertising. It was only the editorial backbone of the executive producer which saved the story from being pulled. It was my last story there.

Then Watkin dusts off the hoary old chestnut of public interest in journalism.

And the main reason I don't see Phil as a journalist is that, when he arrives at work each day, he starts from a fundamentally different place than I do. When I, or another journalist at RNZ, start on a story, we are able-no, expected - to follow the evidence wherever it leads. We are expected to work in the public interest. (Watkin, 2017)

Let us have a look at that lofty idea for a minute. Public interest is the reason why many good journalists are attracted to the job, true, but to see it as the main reason why they head out every day notebooks and phones in hand is naive, bordering on delusional.

As journalists, we would like to believe that our workplaces are like Aaron Sorkin's The Newsroom, where virtue and ethics are the bread and butter of everyday life. But they aren't. Sorry. We don't have aspirational conversations that run over multiple episodes about how we must risk the whole future of the news operation for a story which must be told, even if no-one watches it, for the sake of humanity. I'm afraid things are much more venal.

In my experience, journalists are more likely to be driven by the thrill of the chase. The glory of producing a unique story which has not been told. Ideally, it will provoke a change in the status quo as a reflection of its importance, and 
theirs. Now the competition between journalists for the glory of telling a story which changes things - the highest accolade a journo can receive — often results in improvements for the public interest. Without sounding too much like a cynical old bear, it can be more of a useful side effect than an end goal.

Public interest is more of an aspirational ideal learnt in ethics classes rather than a day-to-day applied truth. Don't get me wrong, it is certainly quoted ad nauseum when journalists want to lift an embargo, dodge a defamation suit or get a suppression order lifted. But never have I heard in my entire quarter century of professional life someone say out loud in the newsroom, as Jeff Daniels' maverick news anchor character might have- 'damn it, all I want us to do that story purely because it's in the public interest.'

Another distorting influence, especially in the commercial world of television is the ever-present sway of entertainment value. This adds a dramatic bias to every story selected. There may be an important story of public interest which needs to be told, we are not talking 'bring the government down' here, but something of moderate importance. If it is a story lacking in pretty pictures or sympathetic attractive characters it will be trumped every time by a story of lesser importance with beautiful vision and photogenic, articulate characters. All of these factors twist the meaning of 'public interest' turning it into something else 'of interest to the public'.

It is argued by Watkin that a journalist at an NGO cannot work for the public interest because they are beholden to their supporters. Actually, I don't think my new job could be any more attuned to the public interest. Without getting too preachy, halting climate change is in all of our interests. There aren't too many people, apart from 'end of days' enthusiasts plumping for the world to heat up so much we can no longer live on it. In this way, the twin fates of the planet and the public converge quite neatly.

I see the small furore over this job title as an illustration of the perception gap between how journalists see themselves and the way in which the public might view them. People are less fussed about where their information comes from. Certainly less fussed than journalists would hope. They are more likely to trust people like themselves on social media than the media or even government. To some extent legacy journalism is stuck in lalaland, believing they are the only trustworthy source of information and they must fight to keep the barbarians from the castle. A healthier response might be to celebrate journalism wherever it happens rather than raising the drawbridge and preparing for a siege.

In addition, there are also some very good practical reasons for calling myself a journalist. If I am to pursue investigations about individuals and corporates committing environmental crimes then this will help me protect my sources. The Greenpeace UK investigative team mentioned earlier relied heavily on a leaked internal document for the BP story. 
Greenpeace New Zealand has set up a securedrop security system so that such documents can be lodged with us anonymously. The same system used by the likes of The Guardian, The New York Times, Washington Post, Vice, CBC and Buzzfeed. It offers whistleblowers full protection. But if I was to be introduced to the person who leaked the information and I wanted to protect my source's identity in court, I need to be recognised as a journalist under NZ law. So it's more than just semantics.

It would be remiss of me as a journalist not to discuss the dangers of bad journalism at NGOs. As Powers points out:

The peril is that it will distractadvocacy groups from theircoreaims and turnjournalism into a platform for fundraising or misleading reporting. (Powers, 2015)

This puts a heavy onus on journalists who practise this new form of journalism to be even more assiduous than their mainstream equivalents about their accuracy and fact checking.

On the upside, if it's done well:

...by taking journalistic values like credibility and fairness seriously, these groups are able to produce the sorts of coverage that news organizations would if they had the time and resources to do so. Moreover, by fusing their reporting with recommendations for taking action, these groups also provide the public with potential solutions to the problems they describe. (Powers, 2015)

Powers is not afraid to use the words journalism and NGO in the same breath and I would encourage such bravery to take hold in New Zealand. It may be easier on the purists if we differentiate NGO journalism from the mainstream by giving it a name.

One possibility is Alternative Journalism as defined by Hirst (2009). He calls it a response to capitalism and imperialism as the global dynamic of domination and consolidation. Citizen Journalism is another iteration of the amateur genre that rose to prominence during the Arab Spring. Especially obvious in places where paid journalists are too frightened to tread and locals pick up their phones and document some of the realities of their lives. There's also Accidental Journalism. Someone who breaks a story by being in the right place at the right time.

Other possible descriptors include, Radical Journalism (popular in the 19th and 20th centuries), Critical Journalism, Activist Journalism and Social Justice Journalism.

My pick though would be the genre of Advocacy Journalism. This is described as journalism where the reporter intentionally and transparently adopts a non-objective point of view usually for some social or political purpose. French newspapers Libération, Charlie Hebdo and L'Humanite all reject the idea of 
pseudo-objective journalism. Perhaps my former colleagues might be more sanguine about the term Advocacy Journalist.

I came across a useful checklist of the tenets of Advocacy Journalism which is worth sharing (Careless, 2000): Being truthful, accurate and credible, acknowledging your perspective, don't ignore your opponents, report embarrassing facts that support the opposition, avoid slogans and ranting, be fair and thorough, and make use of neutral sources to establish facts.

Some of these principles may be tricky to explain to hardcore campaigning organisations but they form part of a vital discussion if the journalists are to remain true to their profession. The benefits of having an advocacy journalist among your ranks are clear for both the organisation and the wider wellbeing of journalism, as Powers concludes:

....the growing presence of such groups in journalism provides an important reminder that solid reporting and heartfelt advocacy need not be polar opposites. At their best, they can be two sides of the same coin. (Powers, 2015)

A National Business Review article on the subject of journalism at Greenpeace (Rotherham, 2017) provoked a lively discussion with lots of journos pitching in but I was heartened by this tweet reaction from a member of the public.

I guess, for me, the defn of 'journalism' is broad, and pieces should be judged on their merits.

In order to stem plunging levels of credibility and adapt to the fast changing digital environment while recognising existing biases within traditional reporting, it may be that mainstream media needs to embrace a more inclusive attitude towards so-called 'NGO journalism'. NGO journalists for their part should ensure that they maintain high levels of factual accuracy and fairness in their work to maintain credibility. If they are concerned about criticism from the mainstream they could perhaps look at adopting more nuanced ways of describing themselves. Advocacy journalist is a descriptor which might acknowledge the intentional and transparent bias which comes with working for a campaigning organisation such as Greenpeace while still maintaining the basic tenet of working for the public interest.

The 30-year-old activist I interviewed is off to lead a Nonviolent Direct Action (NVDA, as they say in the business) in the oil prospecting capital of the country, New Plymouth. By the time you are reading this she might have already been arrested and charged.

Crossing the line is not without its dangers. 


\section{Note}

1. The author was a journalist on both investigative programmes.

\section{References}

Bradbury, M. (2015, December 1). Mediaworks vandalism of journalism continues with its decision to cancel 3D. Retrieved from http://thedailyblog.co.nz/2015/12/01/ mediaworks-vandalism-of-journalism-continues-with-its-decision-to-cancel-3d/

Brown, R. (2016, September 4). Obscuring the news. Retrieved from https://publicaddress.net/hardnews/obscuring-the-news/

Careless, S. (2000, May 15). Every news outlet has its 'bias'. So just what is the difference between the 'alternative' and the 'mainstream' press? Retrieved from http:// www.theinterim.com/issues/society-culture/advocacy-journalism/

Edelman. (2017a). Trust and the US presidential election. Retrieved from http://www. edelman.com/trust2017/trust-and-us-presidential-election/

Edelman. (2017b). Global trust survey. Retrieved from http://www.edelman.com/ trust2017/

Founders of Greenpeace. (2016). Greenpeace International. Retrieved from http://www. greenpeace.org/international/en/about/history/founders/

Henderson, C. (2017, March 15). Sunday is a rare polar bear in the current television climate. Retrieved from http://thespinoff.co.nz/tv/15-03-2017/sunday-is-a-rare-polarbear-in-the-current-television-climate-will-it-survive/

Hirst, M. (2009, July). What is alternative journalism? Retrieved from https://ethicalmartini.wordpress.com/2009/07/13/what-is-alternative-journalism/

Jackson, J. (2015, September 9). Greenpeace hires team of investigative journalists. Retrieved from https:/www.theguardian.com/media/2015/sep/09/greenpeace-hiresinvestigative-journalists-meiron-jones

McClenaghan, M. \& Carter, C. (2016, December 13). Leaked report reveals BP safety failures as it heads back to Gulf of Mexico. Retrieved from http://energydesk.greenpeace.org/2016/12/13/bp-leaked-report-sparks-concerns-safety/

Peacock, C. (2017, March 12). Crossing over to the dark side. Retrieved from http:// www.radionz.co.nz/national/programmes/mediawatch/audio/201836028/crossingover-to-'the-dark-side',

Powers, M. (2015 September 16). When Greenpeace hires journalists it's a doubleedged sword. The Conversation. http://theconversation.com/when-greenpeace-hiresjournalists-its-a-double-edged-sword-47398

Reavy, M. (2013). Objectivity and advocacy in Journalism. Retrieved from https://www. mediaethicsmagazine.com/index.php/browse-back-issues/179-fall-2013-vol-25-no1/3999003-objectivity-and-advocacy-in-journalism

Rotherham, F. (2017, March 16). Greenpeace investigative team to target NZ corporates. Retrieved from https://www.nbr.co.nz/subscribe/200710

Walker, G. (2017, March 16). Greenpeace says its new investigative team will support environmental advocacy work. Retrieved from https://soundcloud.com/nbr-radio/ greenpeace-investigative-team-to-target-nz-corporates

Watkin, T. (2017, March 18). She's a long way to the perfect journalist, boy. Retrieved from http://pundit.co.nz/blogs/tim-watkin 
Phil Vine is a broadcast investigative journalist with 25 years of experience. He now works for Greenpeace in Auckland, New Zealand. He has worked on assignments in places as wide-ranging as Afghanistan, El Salvador, Nicaragua, TimorLeste and Invercargill. He has also worked as a journalist for BBC World and ITV. In New Zealand, he has won several awards working for programmes like 60 Minutes, 20/20 and Fair Go. He blogs at Pundit. (pundit.co.nz/blogs/phil-vine) pvine@greenpeace.org

\section{PACIFIC MEDIA CENTRE}

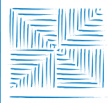

PAEIFIE M를 EENTRE E AMOKURA
The Pacific Media Centre (Te Amokura) focuses on Mãori, Pacific and diversity media and community development. It's the only media research and community resource centre of its kind in Aotearoa/New Zealand.

Pacific Media Centre activities include:

- International book and research publication

- Publication of the peer-reviewed Pacific Journalism Review research journal and Pacific Journalism Monographs

- Publication of Pacific Media Centre Online as a media resource and postgraduate outlet

- Publication of Pacific Media Watch, a regional media monitoring service

- Journalism and media research opportunities

- Asia-Pacific internships for postgraduate students 